\title{
Breeding for Resistance to Soybean Rust
}

\author{
Glen L. Hartman, USDA-ARS, National Soybean Research Center, Department of Crop Sciences, University of \\ Illinois, Urbana 61801; Monte R. Miles, USDA-ARS, National Soybean Research Laboratory, University of Illinois; \\ and Reid D. Frederick, FDWSRU, USDA-ARS, Frederick, MD
}

\begin{abstract}
Hartman, G. L., Miles, M. R., and Frederick, R. D. 2005. Breeding for resistance to soybean rust. Plant Dis. 89:664-666.

Soybean rust occurs in all major soybean-growing regions of the world including the North American mainland. Soybean rust, caused by Phakopsora pachyrhizi, is the most destructive foliar disease of soybean, and yield losses of over 50\% are common when environmental conditions are conducive for disease development. Heavily infected plants defoliate and mature more rapidly than plants not infected with rust. $P$. pachyrhizi has a broad host range and can infect many other legumes including some native to Australia. A number of physiological races of the fungus have been reported on these native legumes from Australia and on soybean. In addition, four single genes for rust resistance were previously identified in four different soybean plant introductions. These sources of resistance also have been reported to be susceptible in some field locations and when challenged with certain isolates of $P$. pachyrhizi. Partial resistance, expressed as reduced pustule number and increased length of latent period, has also been reported but has not been widely used in breeding programs. Yield stability has been used in the past and compares percentage of yields in fungicide and nonfungicide plots. Cultivars or lines with a higher percentage of yield have greater yield stability in the presence of rust. Although soybean rust only recently was found in the continental United States, a proactive project to evaluate the USDA soybean germ plasm collection for rust resistance was initiated in 2002 at the Fort Detrick plant biocontainment facility and at six international locations. Part of this project is to discover soybean lines with greater yield stability, and additional single and partial resistance. To help minimize the impact of soybean rust, the first line of defense will be fungicides, with host resistance and yield stability augmenting the long-term management of soybean rust.
\end{abstract}

The Asian soybean rust, caused by Phakopsora pachyrhizi, has been known to occur in Asia and Australia for over 50 years and was first reported in Japan in 1903 (9). The pathogen was first found in the United States in Hawaii in 1994 (10). After 1994, the pathogen was discovered in several countries in Africa (12) and South America (26). The rapid spread of $P$. pachyrhizi and the potential for severe yield losses makes this potentially the most destructive foliar disease of soybean (23). A soybean rust epidemic in the United States could have a major impact on both total soybean production and production costs in the United States (14).

\section{Host Range}

P. pachyrhizi infects more than 95 species of plants from more than 42 genera

Corresponding author: G. L. Hartman

E-mail: ghartman@uiuc.edu

Accepted for publication 8 December 2004.

DOI: $10.1094 / P D-89-0664$

This article is in the public domain and not copyrightable. It may be freely reprinted with customary crediting of the source. The American Phytopathological Society, 2005. including soybean and related Glycine species $(19,21)$. Species that serve as hosts for $P$. pachyrhizi include many wild and edible legumes, as well as kudzu, an exotic weed that is widespread in the United States. Such a broad host range is unusual among rust pathogens; most rust species have a narrow host range that is limited to a few plant species. The large number of host species that $P$. pachyrhizi infects increases the likelihood that this pathogen will survive and overwinter in the southern United States as well as in Central America. Kudzu, which has been observed with severe rust infections along roadsides in Paraguay, could serve as an inoculum reservoir or bridge host for $P$. pachyrhizi in most parts of the southern United States during colder months in the north. This broad host range also may be the result of genes that contribute to a diverse and complex virulence pattern.

\section{Resistance}

Specific resistance and physiological specialization. Specific resistance to $P$. pachyrhizi is known, and four single dominant genes have been identified as $R p p_{1}$ (17) , Rpp 2 (3), $R_{p p} 3$ (2,3,8), and $R_{p p}$ (7). These four genes condition resistance to a limited set of rust isolates (Table 1). The $R p p_{I}$ was described as having an immune reaction when inoculated with a few isolates, including India 73-1. Inoculation of some rust isolates on $R_{p p}$ or the other genes produces a resistant red-brown (RB) lesion with no or sparsely sporulating uredinia. The RB lesion type is considered to be a resistant lesion type when compared with a fully susceptible TAN lesion (Fig. 1). Single-gene resistance has not been durable, and the usefulness of the sources of single genes was ineffective soon after the sources were identified (11). For example, accession PI230970 was identified as resistant in field evaluations in 1971 to 1973 , but by 1976 a few susceptible lesions were observed on plants in the

Table 1. Named single genes, original sources, and Phakopsora pachyrhizi isolates used in studies of the inheritance of resistance to soybean rust

\begin{tabular}{|c|c|c|c|}
\hline \multirow[b]{2}{*}{ Named single gene } & \multirow{2}{*}{$\begin{array}{l}\text { Accession no. and } \\
\text { cultivar name of } \\
\text { original source }\end{array}$} & \multicolumn{2}{|c|}{ Phakopsora pachyrhizi isolates ${ }^{\mathrm{a}}$} \\
\hline & & Resistant reaction & Susceptible reaction \\
\hline$R p p_{I}$ & $\begin{array}{l}\text { PI200492 } \\
\text { Komata }\end{array}$ & IN $73-1^{b, c}$ & $\begin{array}{c}\text { TW 72-1, TW 80-2 } \\
(8,15)^{\mathrm{d}}\end{array}$ \\
\hline$R_{p p}$ & PI230970 & $\begin{array}{l}\text { AU 72-1 } 1^{\mathrm{c}}, \text { IN } 73-1^{\mathrm{c}} \\
\text { PH } 77-1^{\mathrm{c}}, \text { TW } 72-1^{\mathrm{c}}\end{array}$ & $\begin{array}{l}\text { TW 80-2 } \\
(2,8,15)^{\mathrm{d}}\end{array}$ \\
\hline $\operatorname{Rpp}_{3}$ & $\begin{array}{l}\text { PI462312 } \\
\text { Ankur }\end{array}$ & IN $73-1^{\mathrm{c}}$ & $\begin{array}{c}\text { TW 72-1, TW } 80-2 \\
(8)^{\mathrm{d}}\end{array}$ \\
\hline $\mathrm{Rpp}_{4}$ & $\begin{array}{l}\text { PI459025 } \\
\text { Bing Nan }\end{array}$ & $\begin{array}{c}\text { IN } 73-1^{\mathrm{c}}, \text { TW } 72-1^{\mathrm{c}} \\
\text { TW } 80-2^{\mathrm{c}}\end{array}$ & $(7)^{d}$ \\
\hline
\end{tabular}

\footnotetext{
${ }^{\mathrm{a}} \mathrm{AU}=$ Australia, $\mathrm{IN}=$ India, $\mathrm{PH}=$ Philippines, $\mathrm{TW}=$ Taiwan.

${ }^{\mathrm{b}}$ Immune reaction type.

${ }^{\mathrm{c}}$ Isolates used in original inheritance studies to examine segregation patterns.
}

${ }^{\mathrm{d}}$ Reference citation. 
field. In 1978, most of the lesions found on plants in the field were of the susceptible TAN type (1). Similarly, the cultivar Komata was identified as resistant in germ plasm evaluations done during 1961 to 1963 (1). By 1966, susceptible lesions were found on plants of Komata in field trails, and by the mid-1970s the line was not considered to be a useful source of resistance (11). The resistance in Ankur, identified in the early 1970s (24), was ineffective in the late 1970s (1), providing another example of the ability of $P$. pachyrhizi to overcome single-gene resistance. Only Bing Nan, the source of the $R p p_{4}$ gene, has not been reported to be defeated in the field, although our observations both in the field in Paraguay and greenhouse inoculation tests indicate that it is susceptible to at least some $P$. pachyrhizi isolates.

Soybean rust was of great concern in some countries in Asia. For example, in Taiwan, from the 1960s until the early 1990 s, research on soybean rust focused on epidemiology and resistance $(4,6)$. In Taiwan, there was a very active field program on soybean rust, and many soybean accessions were screened for resistance. Physiological races of $P$. pachyrhizi were first described in 1966 when a set of nine single urediniospore isolates were inoculated onto six soybean and five legume accessions (13). The reactions of the nine isolates were similar on all six of the soybean genotypes, but six pathotypes were identified based upon their reactions on the legume accessions. The first example of virulence diversity on soybean cultivars was described in Queensland, Australia (16), where one rust isolate was found to be virulent on the cultivar Willis but avirulent on the accession PI 200492, while another isolate was virulent on both soybean genotypes. Several other studies have also shown considerable variation in virulence among isolates from the same field as well as isolates collected from wide geographical areas $(20,22)$. Use of single genes to control rust may have some utility, but other options such as using partial resistance may be needed to develop "slow-rusting" cultivars.

Partial resistance. Partial resistance, or rate reducing resistance, is also known in soybean (25). Lines with partial resistance in field evaluations are rated as moderately resistant, since fewer lesions develop on plants throughout the season. In greenhouse studies, host-pathogen combinations that resulted in RB reaction types tended to have longer latent periods, lower rates of increase in pustule number over time, and smaller lesions compared with susceptible interactions that resulted in a TAN reaction type $(2,15)$. Identification and utilization of partial resistance in breeding programs has been limited. The evaluation methods may be time-consuming and difficult to incorporate into breeding programs and therefore limited to use with advanced generations. These difficulties, at least in part, led to the development of a strategy to select genotypes with what was defined as tolerance or yield stability despite being heavily infected with $P$. pachyrhizi $(4,25)$.

Yield stability. Yield stability, or tolerance, refers to the strategy of selecting genotypes with high yield potential and less yield loss from soybean rust. Screening for yield stability to soybean rust was started at the Asian Vegetable Research and Development Center (4), where yields from paired plots, with and without the fungicide Dithane M-45 applied every 2 weeks, were compared for losses due to rust (Table 2). High-yielding genotypes with lower yield loss under severe rust conditions were considered to be tolerant. Rust development rates and estimates of rust severity on foliage were not correlated with yield loss in tolerant materials. Using fungicide protected plots as yield checks,

Table 2. Yield of 12 soybean lines in fungicide-protected plots and in Phakopsora pachyrhiziinoculated plots, and losses observed at the Asian Vegetable Research and Development Center in Taiwan (6)

\begin{tabular}{|c|c|c|c|}
\hline \multirow[b]{2}{*}{ Line } & \multicolumn{2}{|c|}{ Yield (kg/ha) } & \multirow[b]{2}{*}{ Loss $(\%)$} \\
\hline & Fungicide protected & Rust inoculated & \\
\hline AGC 129 & 2,800 & 837 & 70 \\
\hline AGC 181 & 2,279 & 766 & 66 \\
\hline AGC 302 & 2,400 & 1,050 & 57 \\
\hline GC $81118-8-4$ & 2,816 & 471 & 83 \\
\hline GC $82345-20-2$ & 2,864 & 726 & 75 \\
\hline GC 82349-6-1 & 3,440 & 837 & 76 \\
\hline KS 8 & 3,498 & 528 & 85 \\
\hline SRE B-15A & 2,386 & 1,076 & 54 \\
\hline SRE C-56A & 2,567 & 1,818 & 29 \\
\hline SRE C-56e & 2,656 & 1,804 & 31 \\
\hline SRE D-14C & 2,804 & 1,514 & 46 \\
\hline SRE D-14D & 2,605 & 1,502 & 41 \\
\hline FLSD $(P \leq 0.05)^{\mathrm{a}}$ & & 9 \\
\hline FLSD $(P \leq 0.05)^{\mathrm{b}}$ & \multicolumn{2}{|c|}{214} & \\
\hline FLSD $(P \leq 0.05)^{\mathrm{c}}$ & \multicolumn{2}{|c|}{263} & \\
\hline
\end{tabular}

${ }^{a}$ Differences between main plot means.

${ }^{\mathrm{b}}$ Differences between subplots within the same main plot.

${ }^{\mathrm{c}}$ Differences between subplots with different main plots.

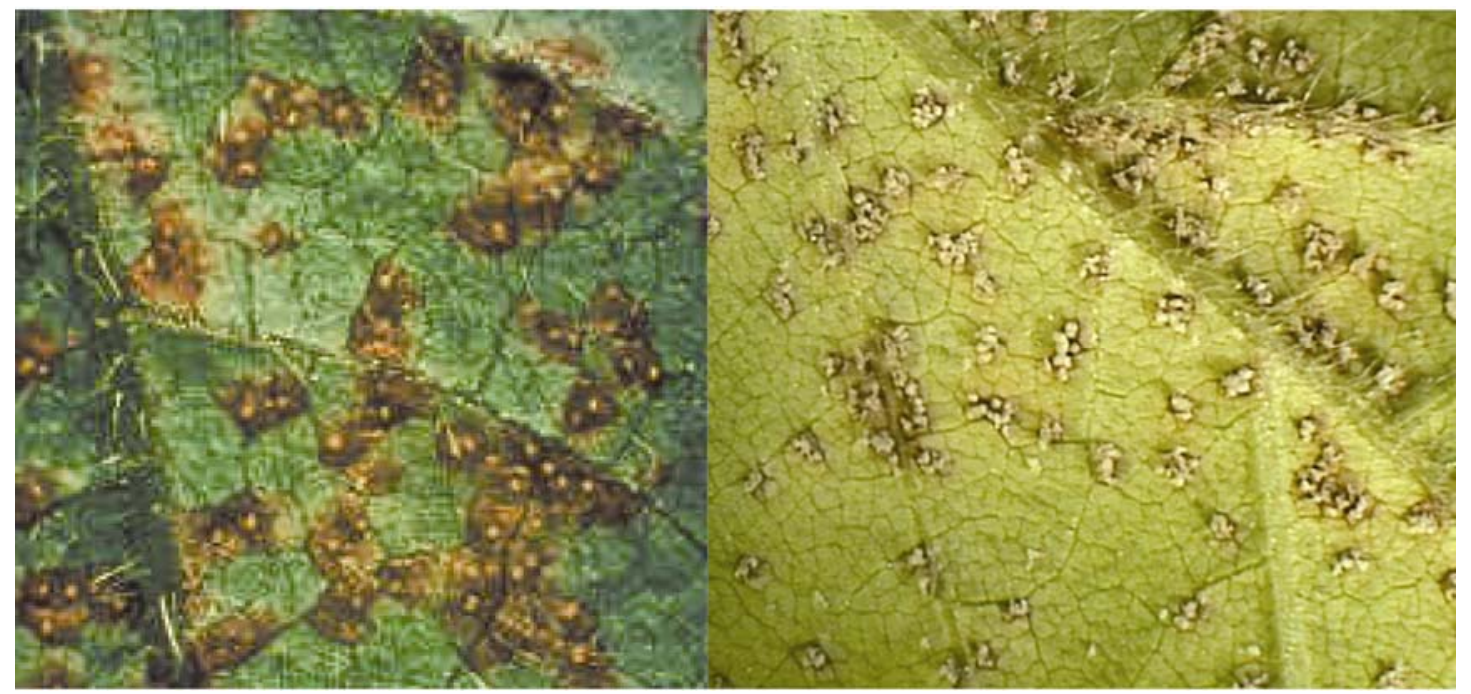

Fig. 1. Soybean leaves infected by Phakopsora pachyrhizi showing (right) susceptible (TAN) lesions and (left) red-brown (RB) lesions. 
tolerant lines from breeding populations were identified without having to take notes on rust severity (4). Cultivars with yield stability may have some partial resistance that was not characterized or selected for in the breeding program.

\section{Current Research}

Since the report of soybean rust in Hawaii in 1994, the USDA-ARS has renewed its support for soybean rust research in the United States. The Foreign Disease-Weed Science Research Unit (FDWSRU) at Fort Detrick, Frederick, MD, is the focal point of this research, with additional collaborators in several states including Illinois and Iowa, and additional support coming from the United Soybean Board. Part of the research focus has been to identify resistant germ plasm. There are more than 16,000 soybean accessions in the USDA Germplasm Collection located at the University of Illinois. These soybean accessions, along with commercial and public cultivars grown in the United States, are being evaluated for resistance to $P$. pachyrhizi in the USDA-ARS FDWSRU Biosafety Level 3 Containment Greenhouses. The germ plasm evaluations are done on seedlings using a mixture of isolates from Africa, Asia, and South America. More than 16,000 soybean accessions have been screened to date; fewer than 800 have been identified as having resistance that needs to be further characterized. None of the U.S. commercial cultivars evaluated were found to be resistant to the mixture of isolates. The soybean accessions showing some level of resistance are being further evaluated using individual isolates to characterize race specific and/or partial resistance. These accessions also have been planted in field trials in Brazil, Paraguay, China, Thailand, South Africa, and Zimbabwe for evaluation of adult plant resistance. Additional research is being conducted to determine the best way to evaluate partial resistance and yield stability. Besides soybean, about 1,000 G. soja accessions have been or will be screened along with some of the perennial Glycine spp. previously reported as having resistance (5). As sources of resistance are identified, crosses will be made to incorporate these resistance traits into adapted backgrounds for commercial use.

\section{Future Management of Soybean Rust}

Once commercial U.S. cultivars are fully evaluated in the field, there will be a recommended list of highly susceptible cultivars that growers should not plant. Additional control of soybean rust can be accomplished through utilization of fungicides (18). Single-gene resistance may or may not be part of the overall picture for control. Although single genes are easy to work with in a backcrossing program, as desirable traits can be moved into elite breeding stock in a relatively short time, $P$. pachyrhizi may easily overcome any single-gene resistance. It may be possible that the right combination of single genes will be useful in a resistance management program. Partial resistance may also contribute to the control of soybean rust in that it will slow down the epidemic, thereby decreasing the buildup of rust spores. Fewer spores produced over time could effectively reduce the need for multiple fungicide applications.

Yield stability, with or without single, stacked, or partial resistance, also may be effective in reducing potential yield losses. Cultivars that show some level of yield stability will be identified. Dealing with yield stability in a breeding program may not be an easy task, since this will require that later generation material be evaluated by comparing yields of plants in plots with rust to plants in plots sprayed with a fungicide to control rust so that percentages of yield among lines based on the control plots can be compared. Each season in the United States without rust provides additional time to evaluate and register fungicides, and test and incorporate resistance and/or yield stability into more adaptable soybean breeding lines.

\section{LITERATURE CITED}

1. Bromfield, K. R. 1984. Soybean rust. Monogr. 11. American Phytopathological Society, St. Paul, MN.

2. Bromfield, K. R., and Hartwig, E. E. 1980. Resistance to soybean rust [Phakopsora pachyrhizi] and mode of inheritance. Crop Sci. 20:254-255.

3. Bromfield, K. R., Melching, J. S., and Kingsolver, C. H. 1980. Virulence and aggressiveness of Phakopsora pachyrhizi isolates causing soybean rust. Phytopathology 70:17-21.

4. Hartman, G. L. 1995. Highlights of soybean rust research at the Asian Vegetable Research and Development Center. Pages 19-28 in: Proc. Soybean Rust Workshop, 9-11 Aug. 1995. J. B. Sinclair and G. L. Hartman, eds. College of Agricultural, Consumer, and Environmental Sciences, National Soybean Research Laboratory, Urbana, IL.

5. Hartman, G. L., Wang, T. C., and Hymowitz, T. 1992. Sources of resistance to soybean rust in perennial Glycine species. Plant Dis. 76:396-399.

6. Hartman, G. L., Wang, T. C., and Tschanz, A. T. 1991. Soybean rust development and the quantitative relationship between rust severity and soybean yield. Plant Dis. 75:596-600.

7. Hartwig, E. E. 1986. Identification of a fourth major gene conferring resistance to soybean rust. Crop Sci. 26:1135-1136.

8. Hartwig, E. E., and Bromfield, K. R. 1983. Relationships among three genes conferring specific resistance to rust in soybeans. Crop Sci. 23:237-239.

9. Hennings, V. P. 1903. [A few new Japanese Uredinaceae]. Hedwigia 42:S107-108.

10. Killgore, E., Heu, R., and Gardner, D. E. 1994.
First report of soybean rust in Hawaii. Plant Dis. 78:1216.

11. Kochman, J. K. 1977. Soybean rust in Australia. Pages 44-48 in: Rust of soybean -- The problem and research needs. INTSOY Series No. 12. R. E. Ford and J. B. Sinclair, eds. University of Illinois, Urbana.

12. Levy, C. 2004. Zimbabwe -- A country report on soybean rust control. Pages 340-348 in: Proc. VII World Soybean Research Conference, IV International Soybean Processing and Utilization Conference, III Congresso Mundial de Soja (Brazilian Soybean Conference). F. Moscardi, C. B. Hoffman-Campo, O. Ferreira Saraiva, P. R. Galerani, F. C. Krzyzanowski, and M. C. Carrão-Panizzi, eds. Emprapa Soybean, Londrina.

13. Lin, S. Y. 1966. Studies on the physiologic races of soybean rust fungus, Phakopsora pachyrhizi Syd. J. Taiwan Agric. Res. 15:24-28.

14. Livingston, M., Johanson, R., Daberkow, S., Roberts, M., Ash, M., and Breneman, V. 2004. Economic and Policy Implications of WindBorne Entry of Asian Soybean Rust into the United States, Electronic Outlook Report from the Economic Research Service, 2004, No. OCS-04D-02. U.S. Dep. Agric.

15. Marchetti, M. A., Uecker, F. A., and Bromfield, K. R. 1975. Uredial development of Phakopsora pachyrhizi in soybeans. Phytopathology 65:822-823.

16. McLean, R. J., and Byth, D. E. 1976. Resistance of soybean to rust in Australia. APPS Newsl. 5:34-36.

17. McLean, R. J., and Byth, D. E. 1980. Inheritance of resistance to rust (Phakopsora pachyrhizi) in soybeans. Aust. J. Agric. Res. 31:951-956.

18. Miles, M. R., Hartman, G. L., Levy, C., and Morel, W. 2003. Current status of soybean rust control by fungicides. Pestic. Outlook 14:197200.

19. Ono, Y., Buritica, P., and Hennen, J. F. 1992. Delimitation of Phakopsora, Physopella and Cerotelium and their species on Leguminosae. Mycol. Res. 96:825-850.

20. Poonpolgul, S., and Surin, P. 1985. Physiological races of soybean rust in Thailand. Thai Phytopathol. 5:119-120.

21. Rytter, J. L., Dowler, W. M., and Bromfield, K. R. 1984. Additional alternative hosts of Phakopsora pachyrhizi, causal agent of soybean rust. Plant Dis. 68:818-819.

22. Shin, D. C., and Tschanz, A. T. 1986. Studies on physiological reactions of soybean cultivars tolerant and susceptible to rust (Phakopsora pachyrhizi Syd.). Korean J. Crop Sci. 31:440-446.

23. Sinclair, J. B., and Hartman, G. L. 1999. Soybean rust. Pages 25-26 in: Compendium of Soybean Diseases. G. L. Hartman, J. B. Sinclair, and J. C. Rupe, eds. American Phytopathological Society, St. Paul, MN

24. Singh, B. B., Gupta, S. C., and Singh, B. D. 1975. Sources of field resistance to rust and yellow mosaic diseases of soybean. Indian J. Genet. Plant Breed. 34:400-404.

25. Wang, T. C., and Hartman, G. L. 1992. Epidemiology of soybean rust and breeding for host resistance. Plant Prot. Bull. Taipei 34:109-124.

26. Yorinori, J. T. 2004. Country report and rust control strategies in Brazil. Pages 447-455 in: Proc. VII World Soybean Research Conference, IV International Soybean Processing and Utilization Conference, III Congresso Mundial de Soja (Brazilian Soybean Conference). F. Moscardi, C. B. Hoffman-Campo, O. Ferreira Saraiva, P. R. Galerani, F. C. Krzyzanowski, and M. C. Carrão-Panizzi, eds. Emprapa Soybean, Londrina. 